\title{
NOTES
}

\section{New Perspectives in the Classification of the Flavobacteria: Description of Chryseobacterium gen. nov., Bergeyella gen. nov., and Empedobacter nom. rev.}

\author{
P. VANDAMME, ${ }^{1 *}$ J.-F. BERNARDET,${ }^{2}$ P. SEGERS, ${ }^{1}$ K. KERSTERS,${ }^{1}$ AND B. HOLMES ${ }^{3}$ \\ Laboratorium voor Microbiologie, University of Ghent, B-9000 Ghent, Belgium ${ }^{1}$; Institut National de la Recherche \\ Agronomique, Unité de Virologie et Immunologie Moléculaires, Centre de Recherches de Jouy-en-Josas, 78352 \\ Jouy-en-Josas Cedex, France ${ }^{2}$; and National Collection of Type Cultures, Central Public Health Laboratory, \\ London NW9 5HT, United Kingdom ${ }^{3}$
}

\begin{abstract}
Our present knowledge concerning the genotypic, chemotaxonomic, and phenotypic characteristics of members of the genus Flavobacterium and some related genera, including the genus Weeksella, was used to revise the classification of these organisms. The generically misclassified organisms Flavobacterium balustinum, Flavobacterium gleum, Flavobacterium indologenes, Flavobacterium indoltheticum, Flavobacterium meningosepticum, and Flavobacterium scophthalmum are included in a new genus, Chryseobacterium, with Chryseobacterium gleum as the type species. The generically misclassified organism Flavobacterium breve is included in the revived genus Empedobacter as Empedobacter brevis, whereas the generically misclassified organism Weeksella zoohelcum is included in the new genus Bergeyella as Bergeyella zoohelcum.
\end{abstract}

The genus Flavobacterium was destined to suffer the same fate as many other long-established genera, as its original description relied on parameters which are now considered to have little taxonomic importance. This ill-defined genus comprised a collection of predominantly yellow-pigmented bacteria that were, according to modern genotypic standards, not at all closely related. Throughout its history, the genus Flavobacterium has been restricted and redefined many times. Most of the organisms once known as flavobacteria have been reclassified (15). The genus Flavobacterium as it is currently defined in Bergey's Manual of Systematic Bacteriology comprises seven distinct species (16): Flavobacterium aquatile (the type species), Flavobacterium balustinum, Flavobacterium breve, Flavobacterium meningosepticum, Flavobacterium multivorum, Flavobacterium odoratum, and Flavobacterium spiritivonum. The type species has been the subject of many discussions. The single strain which represents this taxon is not the original culture described by Frankland and Frankland (9), and it does not fit the original description, although that description was rather meager. For several reasons this strain is considered unrepresentative of the genus, and therefore Holmes and Owen (15) requested that $F$. aquatile be rejected as a nomen dubium and be replaced with $F$. breve as the type species of the genus. The Judicial Commission of the International Committee on Systematic Bacteriology denied this request as there was no great potential for confusion if $F$. aquatile was retained, nor were strong arguments for rejecting this type species found in the International Code of Nomenclature of Bacteria (35). In subsequent taxonomic studies, new Flavobacterium species were described, whereas other were removed and included in new genera $(8,14,17,21,24,29,34,37)$.

The most recent review of the taxonomy of the flavobacteria

\footnotetext{
* Corresponding author. Mailing address: Laboratory of Microbiology, University of Ghent, K. L. Ledeganckstraat 35, B-9000 Ghent, Belgium. Phone: (32)9.264.5114. Fax: (32)9.264.5346.
}

appears in The Prokaryotes, 2nd ed. (13). In this review, flavobacteria are divided into four natural groups, excluding $F$. aquatile. The first group includes $F$. balustinum, $F$. breve, Flavobacterium gleum, Flavobacterium indologenes, Flavobacterium indoltheticum, and $F$. meningosepticum. A second natural group is formed by $F$. odoratum. The third group includes Flavobacterium mizutae, F. multivorum, F. spiritivorum, Flavobacterium thalpophilum, and Flavobacterium yabuuchiae; these organisms form a group considered to be a separate genus, Sphingobacterium $(29,37)$. Finally, two species, formerly known as Centers for Disease Control groups IIf and IIj, constitute a fourth group, for which a separate genus has been proposed $(19,20)$; these taxa are now known as Weeksella virosa, the type species, and Weeksella zoohelcum, respectively $(19,20)$.

An important, additional problem throughout the history of the genus Flavobacterium has been the difficulty of separating this taxon from similar genera, such as Cytophaga and Flexibacter. Differentiation of these genera relies mainly on ultrastructural features, such as gliding motility and cellular morphology $(13,27)$. Not surprisingly, these features have turned out to have limited taxonomic value, and genus delineation has remained troublesome (27). Recently, several phylogenetic analyses have provided new insights concerning the taxonomic relationships within this cluster of organisms, which is often referred to as the Flavobacterium-Cytophaga rRNA cluster (10, $25,28)$. One of the main conclusions of these studies is that the genera Flavobacterium, Cytophaga, and Flexibacter all are polyphyletic and should be redefined and subdivided into several genera. The relationships of these taxa to other members of this rRNA superfamily, such as the genera Capnocytophaga, Ornithobacterium, Riemerella, and Weeksella, have been described in several papers $(10,25,28,33)$ and are partially shown in Fig. 1, which is a schematic compilation of previously published DNA-rRNA hybridization results and new data (1, 31). The results obtained for the flavobacteria indicate that 


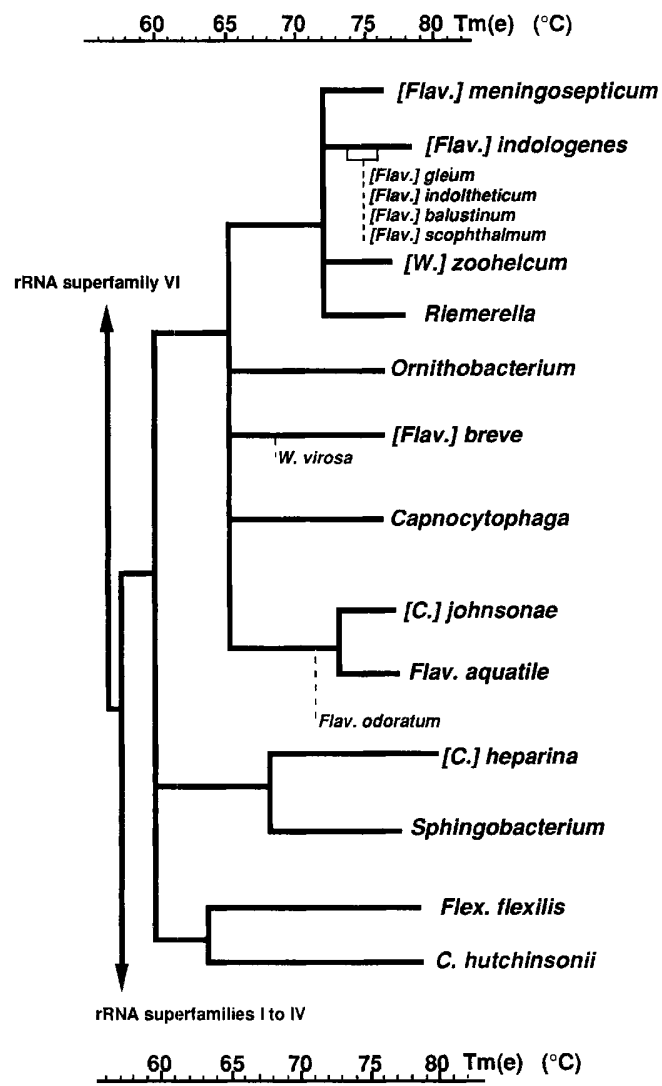

FIG. 1. Simplified rRNA cistron similarity dendrogram for rRNA superfamily V. Abbreviations: C., Cytophaga; Flav., Flavobacterium; Flex., Flexibacter; $W$., Weeksella. Brackets indicate generically misnamed species.

none of the four natural groups described above is closely related to $F$. aquatile.

Within well-characterized genera, differences in melting temperatures $\left[T_{m(e)}\right]$ for the most part range from 4 to $7^{\circ} \mathrm{C}(7)$, whereas differences in $T_{m(e)}$ values of up to $12^{\circ} \mathrm{C}$ are found within bacterial families (32). This implies that, except for $F$. odoratum, all members of the four natural groups sensu Holmes (13) should be excluded from the genus Flavobacterium on genotypic grounds, as the name Flavobacterium must be retained for the type species. The results of phylogenetic analyses have also established that the genus Weeksella, although it contains only two species, is also heterogeneous, as differences in $T_{m(e)}$ values of $12^{\circ} \mathrm{C}$ were measured (28). Again, the genus name must be retained for the type species, which is $W$. virosa. The genus Sphingobacterium, on the other hand, has been found to be genotypically defined, with differences in $T_{m(e)}$ values within this genus of about $8^{\circ} \mathrm{C}$ (Fig. 1) (28). These data also support the transfer of $F$. thalpophilum and $F$. mizutaii to the genus Sphingobacterium as Sphingobacterium thalpophilum and Sphingobacterium mizutae, respectively; these transfers were based mainly on the results of chemotaxonomic studies $(21,29,37)$.

Since a previous report (28), radioactively labeled rRNA probes of the type strains of $F$. meningosepticum, Flexibacter flexilis, and Cytophaga hutchinsonii were prepared in order to further explore the taxonomic relationships of these taxa. The hybridization results obtained with $F$. meningosepticum, Flexibacter flexilis, and Cytophaga hutchinsonii rRNA probes will be discussed in detail elsewhere $(1,31)$. The taxonomic positions of these three taxa within rRNA superfamily $V$ are shown in Fig. 1. From these data it is obvious that the flavobacteria belonging to the first natural group sensu Holmes (13) form a tight rRNA cluster in which $F$. meningosepticum occupies a separate position (Fig. 1). This subdivision into two groups corresponds to the original phenotypic delineation of Centers for Disease Control groups IIa (now $F$. meningosepticum [22]) and IIb ( $F$. balustinum, $F$. gleum, $F$. indologenes, $F$. indoltheticum, and numerous unnamed strains [13]). Flavobacterium scophthalmum, a recently recognized fish pathogen, belongs to the same rRNA cluster (24) (Fig. 1). The following two additional taxa occupy separate positions at the base level between the two groups mentioned above: $W$. zoohelcum and Riemerella anatipestifer (Fig. 1). The genotypic divergence within this rRNA cluster is within the range of divergence of many bacterial genera. Criteria such as chemotaxonomic and classical phenotypic features are decisive for including all or some of these taxa in one genus. An example of such a polyphasic approach is genus delineation in the family $\mathrm{Co}$ mamonadaceae (36). The genera Acidovorax, Aquaspirillum, Comamonas, Hydrogenophaga, Variovorax, and Xylophilus all branch at a base level of about $76^{\circ} \mathrm{C}$, which corresponds to a level of divergence of about $5^{\circ} \mathrm{C}$. Several of these genera (the genera Acidovorax, Aquaspirillum, and Comamonas) include species that occupy separate positions at the same base level (about $76^{\circ} \mathrm{C}$ ) (36). In such cases, phenotypic criteria are decisive for determining the final genus designation. The present situation with $F$. balustinum, $F$. gleum, $F$. indologenes, $F$. indoltheticum, $F$. meningosepticum, $F$. scophthalmum, $R$. anatipestifer, and $W$. zoohelcum is completely analogous. Obviously, $F$. balustinum, $F$. gleum, $F$. indologenes, $F$. indoltheticum, $F$. meningosepticum, and $F$. scophthalmum are similar in many respects. They share many classical phenotypic features $(13,24)$, they all contain menaquinone 6 as their major respiratory quinone $(5,6$; no data have been published for $F$. indoltheticum and $F$. scophthalmum), and they have similar fatty acid profiles which are characterized by large amounts of 15:0 iso, iso $17: 1 \omega 9 \mathrm{c}, 17: 0$ iso $3 \mathrm{OH}$, and summed feature 4 (i.e., $15: 0$ iso $2 \mathrm{OH}$ or $16: 1 \omega 7 \mathrm{t}$ or both $[24,28])$. Within this group, $F$. meningosepticum has the most aberrant fatty acid profile (28). $W$. zoohelcum, conversely, is phenotypically very different from these flavobacteria $(13,20)$ and has a different fatty acid profile (28). Finally, $R$. anatipestifer can be distinguished from its neighbors by several classical phenotypic features, by its capnophilic metabolism, and by its fatty acid and quinone contents (28) (Table 1).

We concluded that separate generic status is warranted for (i) $F$. balustinum, $F$. gleum, $F$. indologenes, $F$. indoltheticum, $F$. meningosepticum, and $F$. scophthalmum (the name Flavobacterium must be preserved for the type species, $F$. aquatile); (ii) $W$. zoohelcum (the name Weeksella must be preserved for the type species, $W$. virosa); and (iii) $R$. anatipestifer. Below, we propose the name Chryseobacterium gen. nov. to include former Flavobacterium species as Chryseobacterium balustinum, Chryseobacterium gleum, Chryseobacterium indologenes, Chryseobacterium indoltheticum, Chryseobacterium meningosepticum, and Chryseobacterium scophthalmum. The two oldest species, Chryseobacterium balustinum (originally described by Harrison in 1929 [12]) and Chryseobacterium indoltheticum (originally described by Campbell and Williams in 1951 [4]), were not chosen as the type species as they have been inadequately characterized and each is currently represented by a single strain (cf. Recommendation $20 \mathrm{~d}$ of the International Code of Nomenclature of Bacteria [23]). Chryseobacterium gleum is a well-characterized species, and both its genotypic 
TABLE 1. Differentiating characteristics of the genus Chryseobacterium and allied bacteria ${ }^{a}$

\begin{tabular}{|c|c|c|c|c|c|c|}
\hline Characteristic & Flavobacterium & Chryseobacterium & Empedobacter & Weeksella & Bergeyella & Riemerella \\
\hline $\mathrm{G}+\mathrm{C}$ content $(\mathrm{mol} \%)$ & 32 & $33-38$ & $31-33$ & $35-38$ & $35-37$ & $29-35$ \\
\hline Respiratory quinone & Menanquinone 6 & Menaquinone 6 & Menaquinone 6 & Menaquinone 6 & ND & Menaquinone 7 \\
\hline Habitat & Free living & $\begin{array}{l}\text { Free living or } \\
\text { parasitic }\end{array}$ & $\begin{array}{l}\text { Free living or } \\
\text { parasitic }\end{array}$ & $\begin{array}{l}\text { Parasitic or } \\
\text { saprophytic }\end{array}$ & $\begin{array}{l}\text { Parasitic or } \\
\text { saprophytic }\end{array}$ & Parasitic \\
\hline Pigment production & $+($ carotenoid $)$ & $+(\text { flexirubin })^{b}$ & + (flexirubin) & - & - & - \\
\hline Saccharolytic metabolism & + & + & + & - & - & + \\
\hline Capnophilic metabolism & - & - & - & - & - & + \\
\hline Resistance to penicillin & ND & + & + & - & - & - \\
\hline DNase activity & ND & $+^{c}$ & + & - & - & ND \\
\hline Gelatinase activity & - & $+^{d}$ & + & + & + & $+e$ \\
\hline Urease activity & - & $\mathrm{v}^{f}$ & - & - & + & $\mathrm{v}^{f}$ \\
\hline Production of indole & - & $\mathrm{v}^{g}$ & + & + & + & - \\
\hline Hydrolysis of esculin & - & $t^{h}$ & - & - & - & ND \\
\hline Growth at $37^{\circ} \mathrm{C}$ & - & + & $v^{i}$ & + & + & + \\
\hline Growth at $42^{\circ} \mathrm{C}$ & - & $\mathrm{v}^{f}$ & - & + & $-j$ & $t^{e}$ \\
\hline Growth on MacConkey agar & - & $t^{k}$ & + & + & - & - \\
\hline Growth on $\beta$-hydroxybutyrate & - & + & + & + & - & ND \\
\hline Acid production from glucose & + & $+l$ & $v^{i}$ & - & - & $\mathrm{v}^{f}$ \\
\hline Acid production from sucrose & + & - & - & - & - & - \\
\hline
\end{tabular}

${ }^{a}$ Data were obtained from Holmes (13), Holmes et al. (16-20), Mudarris et al. (24), Segers et al. (28), and Yabuuchi et al. (37). +, present in all strains; - absent in all strains; $\mathrm{v}$, variable (see below); ND, not determined.

${ }^{b}$ Some Chryseobacterium meningosepticum strains are nonpigmented.

' Present in all Chryseobacterium strains studied except 2 of 12 Chryseobacterium gleum strains. Not determined for Chryseobacterium indoltheticum.

${ }^{d}$ Present in all Chryseobacterium strains studied. Not determined for Chryseobacterium indoltheticum.

${ }^{e}$ Most $R$. anatipestifer strains are positive for this characteristic.

${ }^{f}$ Variable within and between species.

${ }^{g}$ Strain dependent for Chryseobacterium meningosepticum. Present in all other Chryseobacterium species except Chryseobacterium scophthalmum.

${ }^{h}$ Present in all Chryseobacterium strains studied except in 2 of 49 Chryseobacterium meningosepticum strains.

${ }^{i}$ Present in six of seven $E$. brevis strains studied.

' Present in 1 of 30 B. zoohelcum strains studied.

${ }^{k}$ Absent in 7 of 13 Chryseobacterium indologenes strains studied and in all Chryseobacterium scophthalmum strains tested.

${ }^{l}$ Absent in 7 of 49 Chryseobacterium meningosepticum strains studied and in all Chryseobacterium scophthalmum strains tested.

structure and phenotypic structure have been studied in detail (17). We therefore propose that Chryseobacterium gleum should be the type species of the genus Chryseobacterium. Chryseobacterium meningosepticum, which is clinically the most important species of this group and has also been wellcharacterized $(2,3,30)$, was not chosen as the type species as it is the most aberrant member of the genus (Fig. 1) (28). We also propose the name Bergeyella gen. nov., with Bergeyella zoohelcum as the type species.

A similar situation occurs in the rRNA branch comprising $W$. virosa and $F$. breve. The level of genotypic divergence between these taxa is about $6^{\circ} \mathrm{C}(28)$ (Fig. 1), and the two taxa differ in many biochemical features (13) (Table 1). They have considerably different fatty acid compositions (6) but have the same respiratory quinone content (i.e., menaquinone 6 is the major quinone [6]). Logically, these two taxa should be considered members of different genera. Instead of proposing a new name for $F$, breve, we propose that the name Empedobacter, which has been applied previously to the same taxon (26), should be revived. This name was published before 1 January 1980 but was not included on Approved Lists of Bacterial Names (cf. Rule 28a of the International Code of Nomenclature of Bacteria [23]). Below, we revive the name Empedobacter to include $F$. breve as Empedobacter brevis.

Finally, $F$. aquatile is the only member of the genus Flavobacterium that remains in this taxon. It has been stated repeatedly that the description of the genus Flavobacterium given in Bergey's Manual of Systematic Bacteriology (16) is more appropriate for the organisms which we include in the genus Chryseobacterium than for $F$. aquatile $(13,15)$. The description of the genus Chryseobacterium given below corresponds in virtually all respects to that description, whereas the descrip- tion of the genus Flavobacterium will have to be revised. This is a consequence of the decision of the Judicial Commission (35). The $T_{m(e)}$ differences for several generically misnamed Cytophaga and Flexibacter species fall within the generic range of 4 to $7^{\circ} \mathrm{C}$ when the DNAs of these organisms are hybridized with $F$. aquatile rRNA $(1,28)$, and these misnamed organisms share many phenotypic characteristics with $F$. aquatile. A revision of the classification and nomenclature of the genus Flavobacterium, including the taxonomic status of $F$. odoratum, and the relationships between members of this taxon and the generically misnamed flexibacters and cytophagas are the subjects of a forthcoming paper (1).

Description of Chryseobacterium gen. nov. Chryseobacterium (Chry.se.o.bac.te'ri.um. Gr. adj. chryseos, golden; Gr. neut. n. bakterion, a small rod; N. L. neut. n. Chryseobacterium, a yellow rod) cells are gram-negative, nonmotile, non-spore-forming rods with parallel sides and rounded ends; typically the cells are $0.5 \mu \mathrm{m}$ wide and 1 to $3 \mu \mathrm{m}$ long. Intracellular granules of poly- $\beta$-hydroxybutyrate are absent. Aerobic. Chemoorganotrophic. All strains grow at $30^{\circ} \mathrm{C}$; most strains grow at $37^{\circ} \mathrm{C}$. Growth on solid media is typically pigmented (yellow to orange), but nonpigmented strains occur. Colonies are translucent (occasionally opaque), circular, convex or low convex, smooth, and shiny, with entire edges. Positive for catalase, oxidase, and phosphatase activities. Several carbohydrates, including glycerol and trehalose, are oxidized. Strong proteolytic activity occurs. Esculin is hydrolyzed. Agar is not digested. Resistant to a wide range of antimicrobial agents. Additional features are shown in Table 1.

Branched-chain fatty acids (i.e., 15:0 iso, iso $17: 1 \omega 9 \mathrm{c}, 17: 0$ iso $3 \mathrm{OH}$, and summed feature 4 [15:0 iso $2 \mathrm{OH}$ or $16: 1 \omega 7 \mathrm{t}$ or both]) are predominant (28). Sphingophospholipids are ab- 
sent. Menaquinone 6 is the only respiratory quinone. Homospermidine and 2-hydroxyputrescine are the major polyamines in Chryseobacterium indologenes, whereas putrescine and agmatine are minor components (11).

The type species is Chryseobacterium gleum comb. nov. The DNA base composition ranges from 33 to $38 \mathrm{~mol} \%$ guanine plus cytosine. Chryseobacterium species are widely distributed in soil, water, and clinical sources.

The descriptions of Chryseobacterium balustinum (basonym, F. balustinum Harrison 1929), Chryseobacterium gleum (basonym, $F$. gleum Holmes, Owen, Steigerwalt, and Brenner 1984), Chryseobacterium indologenes (basonym, $F$. indologenes Yabuuchi, Kaneko, Yano, Moss, and Miyoshi 1983), Chryseobacterium indoltheticum (basonym, $F$. indoltheticum Campbell and Williams 1951), Chryseobacterium meningosepticum comb. nov. (basonym, F. meningosepticum King 1959), and Chryseobacterium scophthalmum (basonym, $F$. scophthalmum Mudarris, Austin, Segers, Vancanneyt, Hoste, and Bernardet 1994) are the same as the original species descriptions given in references $4,12,16,17,22,24$, and 37 .

Description of Bergeyella gen. nov. Bergeyella (Ber.gey.el'la.; proper name Bergey; L. dim. suff. -ella; N. L. fem. n. Bergeyella, in honor of D. H. Bergey, who created, together with his coworkers, the genus Flavobacterium in 1923, for his contributions to the taxonomy of the genus Flavobacterium and related bacteria).

The description of Bergeyella is the same as the description given previously for Weeksella (19). In addition, the following features differentiate the genus Bergeyella and genuine Weeksella species. Urease activity is present. No growth occurs at $42^{\circ} \mathrm{C}$, on MacConkey agar, or on $\beta$-hydroxybutyrate. Branchedchain fatty acids (15:0 iso, 15:0 iso $2 \mathrm{OH}, 17: 1$ iso, 17:0 iso $3 \mathrm{OH}$ ) are predominant. Sphingophospholipids are absent. The type species is $B$. zoohelcum. The DNA base composition ranges from 35 to $37 \mathrm{~mol} \%$ guanine plus cytosine. The upper respiratory tracts of dogs and human wounds caused by dog bites are the most frequent sources. Pathogenicity is unknown.

The description of $B$. zoohelcum comb. nov. (basonym, $W$. zoohelcum Holmes, Steigerwalt, Weaver, and Brenner 1986) is the same as the description given previously for $W$. zoohelcum (20).

Description of Empedobacter (ex Prévot 1961) nom. rev. Empedobacter (Em.pe.do.bac'ter. Gr. adj. empedos, fixed; M. L. masc. n. bacter, a small rod; M. L. masc. n. Empedobacter, nonmotile rod) cells are gram-negative, nonmotile, non-sporeforming rods with parallel sides and rounded ends; typically the cells are $0.5 \mu \mathrm{m}$ wide and 1 to $2 \mu \mathrm{m}$ long. Intracellular granules of poly- $\beta$-hydroxybutyrate are absent. Aerobic, having a strictly respiratory type of metabolism. Chemoorganotrophic. All strains grow at $30^{\circ} \mathrm{C}$; most strains grow at $37^{\circ} \mathrm{C}$. Growth on solid media is light yellow. Colonies are circular, low convex, smooth, and shiny, with entire edges. Positive for catalase, oxidase, and phosphatase activities. Indole is produced. Several carbohydrates are oxidized, but glycerol and trehalose are not oxidized. Strong proteolytic activity occurs. Esculin is not hydrolyzed. Agar is not digested. Resistant to a wide range of antimicrobial agents.

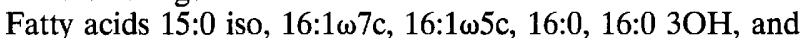
17:0 iso $3 \mathrm{OH}$ are predominant. Sphingophospholipids are absent. Menaquinone 6 is the only respiratory quinone.

The type species is $E$. brevis comb. nov., which has been isolated from water samples and clinical sources. The DNA base composition ranges from 31 to 33 mol\% guanine plus cytosine.

The description of $E$. brevis comb. nov. (basonym, $F$. breve Holmes and Owen 1982 ex Bergey, Harrison, Breed, Hammer, and Huntoon 1923) is the same as the description given previously for $F$. breve $(16,18)$.

Table 1 shows features that differentiate the genera Chryseobacterium, Bergeyella, Empedobacter, Flavobacterium, Riemerella, and Weeksella.

P.V. is indebted to the National Fund for Scientific Research (Belgium) for a position as a postdoctoral research fellow. K.K. is indebted to the Fund for Medical Scientific Research, Belgium, for research and personnel grants. The work of J.-F.B. was supported by a NATO grant.

We are especially grateful to T. O. MacAdoo, Department of Foreign Languages, Virginia Polytechnic Institute and State University, Blacksburg, for his expert advice concerning bacterial nomenclature.

\section{REFERENCES}

1. Bernardet, J.-F., et al. Unpublished data.

2. Bruun, B. 1987. Antimicrobial susceptibility of Flavobacterium meningosepticum strains identified by DNA-DNA hybridization. Acta Pathol. Microbiol. Immunol. Scand. Sect. B 95:95-101.

3. Bruun, B., and J. Ursing. 1987. Phenotypic characterization of Flavobacterium meningosepticum strains identified by DNA-DNA hybridization. Acta Pathol. Microbiol. Immunol. Scand. Sect. B 95:41-47.

4. Campbell, L. L., and O. B. Williams. 1951. A study of chitindecomposing microorganisms of marine origin. J. Gen. Microbiol. 5:894-905.

5. Dees, S. B., G. M. Carlone, D. Hollis, and C. W. Moss. 1985. Chemical and phenotypic characteristics of Flavobacterium thalpophilum compared with those of other Flavobacterium and Sphingobacterium species. Int. J. Syst. Bacteriol. 35:16-22.

6. Dees, S. B., C. W. Moss, D. G. Hollis, and R. E. Weaver. 1986. Chemical characterization of Flavobacterium odoratum, Flavobacterium breve, and Flavobacterium-like groups IIe, IIh, and IIf. J. Clin. Microbiol. 23:267-273.

7. De Ley, J. 1992. The Proteobacteria: ribosomal RNA cistron similarities and bacterial taxonomy, p. 2111-2140. In A. Balows, H. G. Trüper, M. Dworkin, W. Harder, and K.-H. Schleifer (ed.), The prokaryotes, 2nd ed., vol. 2. Springer-Verlag, Berlin.

8. Dobson, S. J., R. R. Colwell, T. A. McMeekin, and P. D. Franzmann. 1993. Direct sequencing of the polymerase chain reactionamplified 16S rRNA gene of Flavobacterium gondwanense sp. nov. and Flavobacterium salegens sp. nov., two new species from a hypersaline antarctic lake. Int. J. Syst. Bacteriol. 43:77-83.

9. Frankland, G. C., and P. F. Frankland. 1889. Ueber einige typische Mikroorganismen im Wasser und im Boden. Z. Hyg. 6:373-400.

10. Gherna, R., and C. R. Woese. 1992. A partial phylogenetic analysis of the "flavobacter-bacteroides" phylum: basis for taxonomic restructuring. Syst. Appl. Microbiol. 15:513-521.

11. Hamana, K., and S. Matsuzaki. 1991. Polyamine distributions in the Flavobacterium-Cytophaga-Sphingobacterium complex. Can. J. Microbiol. 37:885-888.

12. Harrison, F. C. 1929. The discoloration of halibut. Can. J. Res. 1:214-239.

13. Holmes, B. 1992. The genera Flavobacterium, Sphingobacterium, and Weeksella, p. 3620-3630. In A. Balows, H. G. Trüper, M. Dworkin, W. Harder, and K.-H. Schleifer (ed.), The prokaryotes, 2nd ed., vol. 4. Springer-Verlag, Berlin.

14. Holmes, B., D. G. Hollis, A. G. Steigerwalt, M. J. Pickett, and D. J. Brenner. 1983. Flavobacterium thalpophilum, a new species recovered from human clinical material. Int. J. Syst. Bacteriol. 33:677682.

15. Holmes, B., and R. J. Owen. 1979. Proposal that Flavobacterium breve be substituted as the type species of the genus in place of Flavobacterium aquatile and emended description of the genus Flavobacterium: status of the named species of Flavobacterium. Int. J. Syst. Bacteriol. 29:416-426.

16. Holmes, B., R. J. Owen, and T. A. McMeekin. 1984. Genus Flavobacterium Bergey, Harrison, Breed, Hammer, and Huntoon $1923,97^{\text {AL }}$, p. 353-361. In N. R. Krieg and J. G. Holt (ed.), 
Bergey's manual of systematic bacteriology, vol. 1. The Williams \& Wilkins Co., Baltimore.

17. Holmes, B., R. J. Owen, A. G. Steigerwalt, and D. J. Brenner. 1984. Flavobacterium gleum, a new species found in human clinical specimens. Int. J. Syst. Bacteriol. 34:21-25.

18. Holmes, B., J. J. S. Snell, and S. P. Lapage. 1978. Revised description, from clinical strains, of Flavobacterium breve (Lustig) Bergey et al. 1923 and proposal of the neotype strain. Int. J. Syst. Bacteriol. 28:201-208.

19. Holmes, B., A. G. Steigerwalt, R. E. Weaver, and D. J. Brenner. 1986. Weeksella virosa gen. nov., sp. nov. (formerly Group IIf), found in human clinical specimens. Syst. Appl. Microbiol. 8:185190.

20. Holmes, B., A. G. Steigerwalt, R. E. Weaver, and D. J. Brenner. 1986. Weeksella zoohelcum sp. nov. (formerly Group IIj), from human clinical specimens. Syst. Appl. Microbiol. 8:191-196.

21. Holmes, B., R. E. Weaver, A. G. Steigerwalt, and D. J. Brenner. 1988. A taxonomic study of Flavobacterium spiritivorum and Sphingobacterium mizutae: proposal of Flavobacterium yabuuchiae sp. nov. and Flavobacterium mizutaii comb. nov. Int. J. Syst. Bacteriol. 38:348-353.

22. King, E. O. 1959. Studies on a group of previously unclassified bacteria associated with meningitis in infants. Am. J. Clin. Pathol. 31:241-247.

23. Lapage, S. P., P. H. A. Sneath, E. F. Lessel, V. B. D. Skerman, H. P. R. Seelinger, and W. A. Clark (ed.). 1992. International code of nomenclature of bacteria. 1990 revision. American Society for Microbiology, Washington, D.C.

24. Mudarris, M., B. Austin, P. Segers, M. Vancanneyt, B. Hoste, and J. F. Bernardet. 1994. Flavobacterium scophthalmum sp. nov., a pathogen of turbot (Scophthalmus maximus L.). Int. J. Syst. Bacteriol. 44:447-453.

25. Nakagawa, Y., and K. Yamasato. 1993. Phylogenetic diversity of the genus Cytophaga revealed by 16S rRNA sequencing and menaquinone analysis. J. Gen. Microbiol. 139:1155-1161.

26. Prévot, A. R. 1961. Traité de systématique bactérienne. Dunod, Paris.

27. Reichenbach, H. 1989. Order I. Cytophagales Leadbetter 1974, 99 $9^{\mathrm{AL}}$, p. 2011-2013. In J. T. Staley, M. P. Bryant, N. Pfennig, and J. G. Holt (ed.), Bergey's manual of systematic bacteriology, vol. 3. The Williams \& Wilkins Co., Baltimore.

28. Segers, P., W. Mannheim, M. Vancanneyt, K. De Brandt, K.-H. Hinz, K. Kersters, and P. Vandamme. 1993. Riemerella anatipes- tifer gen. nov., comb. nov., the causative agent of septicemia anserum exsudativa, and its phylogenetic affiliation within the Flavobacterium-Cytophaga rRNA homology group. Int. J. Syst. Bacteriol. 43:768-776.

29. Takeuchi, M., and A. Yokota. 1992. Proposals of Sphingobacterium faecium sp. nov., Sphingobacterium piscium sp. nov., Sphingobacterium heparinum comb. nov., Sphingobacterium thalpophilum comb. nov., and two genospecies of the genus Sphingobacterium, and synonymy of Flavobacterium yabuuchiae and Sphingobacterium spiritivorum. J. Gen. Appl. Microbiol. 38:465-482.

30. Ursing, J., and B. Bruun. 1987. Genetic heterogeneity of Flavobacterium meningosepticum demonstrated by DNA-DNA hybridization. Acta Pathol. Microbiol. Immunol. Scand. Sect. B 95:33-39.

31. Vancanneyt, M., P. Segers, L. Hauben, J. Hommez, L. A. Devriese, B. Hoste, P. Vandamme, and K. Kersters. Flavobacterium meningosepticum, a pathogen in birds. Submitted for publication.

32. Vandamme, P., and J. De Ley. 1991. Proposal for a new family, Campylobacteraceae. Int. J. Syst. Bacteriol. 41:451-455.

33. Vandamme, P., P. Segers, M. Vancanneyt, K. Van Hove, R. Mutters, J. Hommez, F. Dewhirst, B. Paster, K. Kersters, E. Falsen, L. A. Devriese, M. Bisgaard, K.-H. Hinz, and W. Mannheim. 1994. Ornithobacterium rhinotracheale gen. nov., sp. nov., isolated from the avian respiratory tract. Int. J. Syst. Bacteriol. 44:24-37.

34. Wakabayashi, H., G. J. Huh, and N. Kimura. 1989. Flavobacterium branchiophila sp. nov., a causative agent of bacterial gill disease of freshwater fishes. Int. J. Syst. Bacteriol. 39:213-216.

35. Wayne, L. G. 1982. Actions of the Judicial Commission of the International Committee on Systematic Bacteriology on requests for opinions published between July 1979 and April 1981. Int. J. Syst. Bacteriol. 32:464-465.

36. Willems, A., M. Goor, S. Thielemans, M. Gillis, K. Kersters, and J. De Ley. 1992. Transfer of several phytopathogenic Pseudomonas species to Acidovorax as Acidovorax avenae subsp. avenae subsp. nov., comb. nov., Acidovorax avenae subsp. citrulli, Acidovorax avenae subsp. cattleyae, and Acidovorax konjaci. Int. J. Syst. Bacteriol. 42:107-109.

37. Yabuuchi, E., T. Kaneko, I. Yano, C. W. Moss, and N. Miyoshi. 1983. Sphingobacterium gen. nov., Sphingobacterium spiritivorum comb. nov., Sphingobacterium multivorum comb. nov., Sphingobacterium mizutae sp. nov., and Flavobacterium indologenes sp. nov.: glucose-nonfermenting gram-negative rods in CDC groups IIK-2 and IIb. Int. J. Syst. Bacteriol. 33:580-598. 